\title{
CRIAR LEITORES PARA UMA SOCIEDADE DEMOCRÁTICA ${ }^{1}$
}

José Morais ${ }^{2}$

\section{RESUMO}

Depois de uma breve descrição das três condições ou fases da aprendizagem da leitura e da escrita num sistema alfabético, examino as consequências das desigualdades socioeconômicas e socioculturais quer sobre a entrada no processo de alfabetização e no seu decurso, quer sobre o desenvolvimento cognitivo de maneira mais geral. Como o acesso à literacia por todos ou, ao contrário, apenas por uma elite também tem consequências para o modo de governo da sociedade, na terceira e última parte deste artigo discuto o que, ao longo dos séculos, já foi democracia e o que esta deveria realmente ser, assim como a contribuição que podem ter, para a construção de uma verdadeira democracia, a universalização da literacia e de uma cultura baseada no pensamento livre e crítico.

Palavras-chave: Literacia. Alfabetização. Plasticidade cerebral. Desigualdades socioeconômicas. Democracia. Educação.

O presente artigo está organizado da forma que segue. Na primeira parte, resumo os principais aspetos cognitivos da aprendizagem da leitura e da escrita. $\mathrm{Na}$ segunda, examino os efeitos das desigualdades socioeconômicas e socioculturais no desenvolvimento cognitivo, incluindo a alfabetização. E, na terceira, indico o que, em minha opinião, é a democracia, e porque razão a universalização da leitura e da escrita são indispensáveis na construção de uma autêntica democracia.

\section{A LEITURA E SUA APRENDIZAGEM}

Para entendermos corretamente as questões relacionadas com a aprendizagem da leitura, devemos ter em conta as relações entre a leitura/escrita e a linguagem. 


\subsection{Leitura/Escrita e Linguagem}

A leitura e a escrita foram consideradas em alguns meios educacionais, em particular norte-americanos e franceses, como outra forma de linguagem, que deveria ser adquirida segundo os mesmos mecanismos. A recomendação desse movimento era "aprender a ler como se aprende a falar, naturalmente". Ainda hoje há, ocasionalmente, quem afirme o mesmo. Porém, não é esta a posição da psicolinguística cognitiva. O psicólogo da linguagem Alvin Liberman (1995) insistiu nas seguintes diferenças entre a fala e a leitura/escrita:

1) a fala é universal; a leitura e a escrita são relativamente raras;

2) a fala é muito mais antiga na história da espécie;

3) a fala aparece cedo na história do indivíduo, a leitura e a escrita só depois;

4) a fala não precisa ser ensinada, mas a leitura e a escrita sim (a simples exposição a um ambiente letrado não é suficiente);

5) a linguagem oral exprime e transmite uma variedade infinita de mensagens, a escrita só partilha esta propriedade na medida em que transcreve a linguagem oral ou a fala interna do pensamento.

Todas essas diferenças resultam de a fala ser um produto da evolução biológica, ao passo que os sistemas de escrita são artefatos. A criança foi preparada pela evolução para a linguagem oral, para compreendê-la e para produzi-la, mas não para ler e escrever. No entanto, a aprendizagem e o ensino da leitura e da escrita podem e devem fundar-se nos laços que as unem à linguagem oral. Os sistemas de escrita, e o alfabeto em particular, foram criados aproveitando constituintes estruturais e processos da linguagem oral, um mecanismo que em biologia foi chamado de "exaptação".

Liberman falou também de outra diferença, que hoje sabemos ser só parcialmente correta:

6) Há mecanismos cerebrais que evoluíram com a linguagem, dedicados aos seus processos (isto é correto), mas não há especialização para a leitura e a escrita enquanto tais (isto não é verdade porque, na realidade, certas regiões cerebrais foram recicladas para se especializarem na leitura e na escrita).

Convém termos em conta que a atividade de leitura mobiliza conhecimentos, capacidades e processos que são comuns à compreensão da escrita e da fala: 
conhecimento do vocabulário, da morfologia, da sintaxe e da semântica, capacidade de raciocínio, de memória de trabalho e de memória de longo prazo, de atenção, e também imagens mentais, evocação de sentimentos e emoções, etc. Porém, aprender a ler é adquirir uma habilidade específica, a habilidade de identificar as palavras escritas.

Podemos observar essa distinção num estudo, realizado nos Estados Unidos, que utilizou o português do Brasil (BUCHWEITZ et al., 2009). Os participantes ouviam ou liam afirmações simples e deviam decidir se eram verdadeiras ou falsas. $\mathrm{Na}$ ressonância magnética funcional, verificou-se que as áreas associadas à compreensão e à tomada de decisão foram ativadas em comum pela apresentação escrita e oral. A apresentação oral ativou mais do que a escrita as áreas associadas ao processamento auditivo e fonológico, e a apresentação escrita ativou mais do que a oral uma pequena área na parte ventral e posterior do giro fusiforme do hemisfério esquerdo. Temos portanto aqui a confirmação, no cérebro, da dissociação entre os dois constituintes da atividade de leitura: uma, a que está associada à compreensão, é partilhada com a escuta, a outra é específica da leitura.

De fato, a leitura utiliza uma área cerebral que foi reciclada para este fim. Essa área ocupava-se na criança pré-letrada do processamento e da identificação de formas visuais e objetos, incluindo rostos. No leitor, é chamada de visual word form area (doravante, VWFA) ou área da forma visual das palavras (COHEN et al., 2000). Ela adquire as características funcionais apropriadas à leitura à medida que o indivíduo, criança ou adulto, aprende a ler.

Em Dehaene et al. (2010), estudo realizado na França e no Brasil, testamos o desempenho de grupos de adultos com diferentes níveis de alfabetização, desde analfabetos a letrados, portugueses e brasileiros, e observamos que, durante a exposição a frases escritas, a ativação cerebral dos participantes é tanto maior quanto maior é a sua habilidade de leitura. A ativação da VWFA é inexistente nos analfabetos, intermediária nos ex-analfabetos e atinge os valores mais altos nos letrados que aprenderam a ler na infância.

\subsection{Uma questão de definição: o que é leitura?}

Para entendermos o que é leitura, retomemos a distinção entre as áreas que se ocupam da compreensão da linguagem, oral ou escrita, e a área, muito mais 
limitada, que realiza a identificação das palavras escritas. Há quem diga que ler é compreender. Se ler fosse compreender, então não se desenvolveria no cérebro uma área que só reage às palavras escritas e que, sem a ativação de outras áreas, não permite a compreensão. Certamente o objetivo da leitura é compreender o que se lê. Mas o próprio fato de estarmos todos de acordo com esta afirmação: "o objetivo da leitura é compreender o que se lê", revela que a compreensão não é o que caracteriza especificamente a leitura. Como a definição de uma coisa deve indicar o que the é específico e não o que ela partilha com outras coisas, não podemos definir a leitura pela compreensão.

No meu livro intitulado $A$ arte de ler, publicado em versão brasileira em 1996, referi-me a uma história que se pensa ser verídica e que, mais tarde, voltei a encontrar num romance escrito por um francês, de 68 anos, que dedicara a sua vida à luta contra o iletrismo (esta palavra, pouco corrente Brasil, é utilizada em Portugal e corresponde à palavra francesa "illettrisme").

Numa cena do romance, descreve-se um colóquio sobre o iletrismo. No fim do colóquio, depois de uma senhora ter falado sobre o seu método para ensinar a ler, e ter repetido que "ler é compreender, é dar sentido", um desconhecido pediu a palavra e falou de um poeta inglês, Milton, que, tendo cegado e não podendo ler, ensinara as filhas a pronunciar o que estava escrito nas obras de que gostava, e isso em línguas que elas desconheciam. Elas só pronunciavam as palavras sem compreender, mas ele compreendia ao escutá-las, como o teria feito um analfabeto. "E o homem perguntara: nesta história, quem lia? Segundo o que ele ouvira no colóquio, não podiam ser as filhas porque pronunciavam sons sem compreender, nem o pai, que só escutava e compreendia, tal como as pessoas na sala o escutavam e compreendiam. Se nesta história ninguém lia, era de virar maluco".

A resposta correta é: havia com certeza alguém que lia, as filhas de Milton. Elas liam, uma vez que transformavam linguagem escrita em linguagem oral. Milton não lia, compreendia o que ouvia. A história de Milton é portanto um caso, muito raro mas demonstrativo, da distinção entre as duas componentes da atividade de leitura, a identificação das palavras escritas e a compreensão do texto. 


\subsection{O Processo de Alfabetização}

Vejamos em seguida quais são as linhas gerais do processo de alfabetização. Para isso devemos começar por considerar o que é o alfabeto. $O$ alfabeto é um sistema de escrita fonográfico, isto é, ele representa a estrutura fonológica da linguagem oral, e o faz especificamente ao nível dos fonemas. Os fonemas não são sons, são unidades fonológicas abstratas.

Observemos, por exemplo, a representação física da palavra "camembert". Podemos facilmente isolar as suas três sílabas, mas não podemos isolar fisicamente os seus fonemas. Na palavra falada "camembert", há essencialmente três emissões de voz, três sílabas. Vejamos agora uma representação esquemática das diferentes sílabas iniciadas pela consoante oclusiva dental sonora. Podemos compreender por que razão este fonema não é isolável. É porque a sua expressão física resulta da coarticulação com a vogal que o acompanha. Em cada uma daquelas sílabas ouvimos a mesma consoante, mas não há nenhum segmento que the corresponda de maneira invariável. A consoante e a vogal combinam-se.

É sem dúvida muito interessante que, apesar dessa variabilidade física, ouçamos sempre a mesma consoante. Nós ouvimos, sim. Porém, as crianças, antes de serem alfabetizadas, ouvem o som da sílaba globalmente e não têm a impressão de ouvir a consoante enquanto tal.

Assim como as crianças pré-alfabetizadas, também os adultos analfabetos não têm essa impressão. Isso foi mostrado há mais de 30 anos por um grupo de pesquisa do nosso laboratório em colaboração com Luz Cary, da Universidade de Lisboa, utilizando tarefas tais como repetir uma expressão sem o seu pedacinho inicial (MORAIS et al., 1979). É a aprendizagem da leitura e da escrita alfabéticas que nos dá a impressão de ouvir a consoante. Por quê? Porque nós aprendemos a representar essa unidade abstrata - a que os linguistas chamam fonema - por uma letra ou, em certos casos, por um grupo de letras (como o /õ/ de "som" e o /a/ de "chá"). Essa contrapartida do fonema na escrita chama-se grafema.

Muitas pessoas dizem que as letras representam sons, mas não é verdade. As letras têm nome e podem ser identificadas por um segmento fônico. Por exemplo, o nome da letra B é "bê". Para transmitir o seu valor fonológico, diz-se que o som de B é "be". Mas "be" é um segmento fônico, uma sílaba em que a vogal é reduzida. A criança a quem se diz que BA é [be + a] não vai ler "ba", vai ler "bea". Ler "ba" 
implica ter tido a intuição de que a consoante representa, não um som, mas um valor fonológico abstrato, um fonema.

O processo de alfabetização envolve três aquisições.

A primeira é a que acabamos de considerar: a compreensão do princípio alfabético, isto é, que as letras ou grupos de letras não correspondem a sons, mas a fonemas.

A segunda aquisição é a do mecanismo elementar da leitura e da escrita. Aprender a ler uma palavra, por exemplo monossilábica, é aprender a identificar os grafemas que a constituem, a associar-lhe os fonemas correspondentes e a reunilos na ordem correta num único som. Aprender a escrevê-la é aprender a analisar a palavra nos seus fonemas, a fazer corresponder, a cada fonema, o grafema e, portanto, a letra ou letras apropriadas e a escrever estas na ordem correta. Esses são os mecanismos elementares do processo de decodificação, utilizado na leitura, e do processo de codificação, utilizado na escrita.

Esses mecanismos, para se tornarem eficientes, têm de ser praticados. Com a prática da leitura e da escrita, o aluno cria unidades fonológicas e ortográficas maiores do que o fonema e o grafema, respectivamente. São geralmente sílabas frequentes, e fonogramas, por exemplo desinências verbais como “-ava”, "-ia”, etc.

É especialmente importante que o aluno aprenda a identificar as fronteiras de sílaba na palavra, porque elas condicionam a interpretação fonológica de muitas letras que se encontram no fim de uma sílaba ou no início da seguinte, por exemplo da letra "n" em "manta" e "mana". As fronteiras de sílaba também ajudam o aluno a resolver as dificuldades associadas a certos encontros consonantais como "altas" vs. "atlas", "marco" vs. "macro".

Sabe-se que as crianças disléxicas têm dificuldades para analisar a fala em fonemas. Têm também outras dificuldades cuja origem parece ser fonológica. Elas, e muitas outras que são más leitoras sem serem realmente disléxicas, não detectam facilmente as fronteiras de sílabas quando a sequência de letras não é do tipo CVCV. Os mecanismos de decodificação, não só os elementares mas também os contextuais, deveriam estar operacionais ao fim de um ano de alfabetização.

A terceira aquisição é a da consolidação, numa forma de memória a longo prazo, das representações ortográficas das palavras que se teve a ocasião de decodificar ou codificar corretamente e rapidamente várias vezes. A decodificação e a codificação conscientes, controladas e sequenciais, isto é, do início para o fim da 
palavra, não são mais necessárias para as palavras conhecidas. As suas representações ortográficas passam a ser ativadas de maneira automática, sem necessidade de controle consciente e na base de um processamento em paralelo dos diferentes constituintes da palavra. Isso pode ser observado, por exemplo, através da redução e finalmente da anulação do efeito do comprimento da palavra na latência da sua identificação em função do número de vezes em que foi apresentada (MALONEY et al., 2009).

A segunda e a terceira aquisição sobrepõem-se numa medida variável ao longo do processo de alfabetização. Como é previsível, a decodificação e a codificação continuam a ser necessárias para as palavras vistas pela primeira vez e para aquelas que foram raramente encontradas. Com o passar dos anos, a proporção dessas palavras é cada vez menor. Além disso, o grau de prática e de habilidade também difere muito entre os alunos. Segundo dados obtidos num estudo não publicado que dirigi em Portugal, no segundo ano de alfabetização ainda são poucas as crianças que se caracterizam por este tipo de processamento; e no quinto ano, pelo contrário, a grande maioria é capaz de reconhecimento automático.

Considerando as características do código ortográfico do português e admitindo que a instrução é apropriada, a grande maioria dos alunos deve estar alfabetizada, isto é, ser capaz de ler e escrever com autonomia, no termo do $1^{\circ}$ ano de escola. Quanto à leitura e à escrita hábeis, automatizadas, elas podem já ser dominantes no termo do $4^{\circ}$ ano. Assim, proponho que se distinga entre 0 alfabetizado e o letrado (equivalente ao termo inglês literate, aquele que adquiriu a capacidade de literacy e usufrui dessa capacidade). A palavra "literacia" recobre dois sentidos, o de capacidade para ler e escrever, e o de uso produtivo dessa capacidade. Não me alongarei aqui sobre esta questão.

Para terminar esta síntese sobre a alfabetização, farei ainda uma breve referência ao que ocorre no cérebro. Durante a aprendizagem, há uma correlação positiva entre a amplitude da ativação da VWFA em resposta a palavras e o desempenho em testes de decodificação grafofonológica, o que revela o papel causal da decodificação na constituição da VWFA. De maneira coerente com essa constatação, a criança disléxica que tem dificuldades nas habilidades fonológicas pertinentes para a leitura apresenta ativações de fraca amplitude na VWFA que aumentam depois de reeducação fonológica (TEMPLE et al., 2004). 


\section{OS EFEITOS DAS DESIGUALDADES SOCIOECONÔMICAS E SOCIOCULTURAIS NA COGNIÇÃO E NA LITERACIA}

De modo geral, na origem das desigualdades entre os indivíduos estão os genes e as experiências. As experiências mudam-nos porque somos plásticos, e a plasticidade é uma características genética: somos geneticamente determinados para sermos mais ou menos plásticos, o que faz com que alguns indivíduos se adaptem melhor do que outros às estimulações.

Esta ideia pode ser ilustrada pelo seguinte fato. As crianças com comportamentos de oposição na escola e uma certa variante do gene DRD4 (que codifica um receptor da dopamina, com influência nos mecanismos da atenção, da motivação e da gratificação) mostraram menos comportamentos de oposição um ano depois de terem participado em sessões em que as mães reagiam de maneira pronta e adequada. Isso não aconteceu com as crianças que não tinham a variante do gene (BACKERMANS-KRANENBURG et al., 2008). Pode, portanto, concluir-se que houve neste caso uma interação entre o gene e a intervenção.

Do mesmo modo, a contribuição dos genes varia com o Estatuto Social. Em geral, nos estudos realizados, o Estatuto Social é uma variável multidimensional que compreende índices de recursos econômicos (por exemplo, rendimento) e de estatuto sociocultural (por exemplo, nível de instrução). Num estudo de Turkheimer et al. (2003), observou-se que $60 \%$ da variância no Ql em crianças gêmeas de famílias de Estatuto Social baixo se explicava pelo ambiente comum, sendo a contribuição dos genes quase nula. Nas famílias de Estatuto Social elevado, observou-se a relação inversa. Isto quer dizer que o Estatuto Social baixo limita o aproveitamento das possibilidades genéticas, ao contrário do Estatuto Social elevado.

Felizmente, o impacto do Estatuto Social baixo pode ser diminuído. Com aquela mesma amostra de crianças, Tucker-Drob (2012) comparou as que tinham e as que não tinham ingressado na pré-escola (as primeiras aos 4 anos). A parte da influência do Estatuto Social no desempenho, avaliado aos 5 anos, em matemática (M) e em leitura (L) foi maior para as que não estiveram na pré-escola $(72 \%$ e $73 \%$ da variabilidade, para $\mathrm{M} \mathrm{e} \mathrm{L}$, respectivamente) do que para as que estiveram (47\% e $43 \%$ ). A educação pré-escolar pode ser portanto um instrumento de redução das desigualdades. 


\subsection{O que representa nascer e desenvolver-se numa família pobre econômica e culturalmente}

Nascer numa família de baixo nível de instrução é causa não só de viver pior como de viver menos, o que é demonstrado pela seguinte cadeia de fatos.

O stress crônico associado a um Estatuto Social inferior conduz a um envelhecimento celular mais rápido. Esse envelhecimento celular pode ser estimado pelo comprimento dos telômeros (sequências repetitivas de aminoácidos nas pontas dos cromossomos) que se reduz com a idade, a inflamação e o stress.

Ora, observou-se que o comprimento dos telômeros dos leucócitos (células do sistema imunitário) está associado à educação dos pais, em crianças de 7 a 13 anos, mesmo depois de ter-se em conta o rendimento da família. Comparadas às crianças que tinham pelo menos um genitor com educação superior, aquelas cujos pais nunca frequentaram o ensino superior tinham telômeros mais curtos, preditivos de uma redução de longevidade de seis anos (NEEDHAM et al., 2012). Assim, as disparidades no envelhecimento celular são evidentes desde a infância e estão associadas ao nível de instrução dos pais. Os nossos pais dão-nos a vida, mas esta pode estar hipotecada desde a infância. Por um encadeamento de efeitos, se têm menos instrução vivemos menos, se têm mais vivemos mais.

Note-se, no entanto, que a escolarização pode compensar em parte a influência do Estatuto Social. $O$ aumento de 8 a 9 anos na escolaridade obrigatória na Suécia em 1949 conduziu a uma redução da mortalidade aos 40 anos (LAGER; TORSSANDER, 2012). Na Noruega, numa situação análoga de aumento da escolaridade de 7 para 9 anos, observou-se que os scores de QI medidos aos 19 anos mostraram um efeito positivo substancial (BRINCH e GALLOWAY, 2012). Em matéria de esperança de vida e de desempenho cognitivo, o que um Estatuto Social baixo tira, a escola pode de algum modo repor, pelo menos parcialmente.

O desenvolvimento do cérebro é influenciado pela estimulação precoce. Por exemplo, o apoio maternal entre os 3 e os 5 anos prediz o volume dos hipocampos, estrutura profunda situada sob o córtex, entre os 7 e os 13 anos (LUBY et al., 2012). Os hipocampos intervêm na consolidação das informações na memória e fornecem ao córtex pré-frontal um conjunto de cenários possíveis que este pode utilizar como material nos seus processos de raciocínio. Ora, ambas as estruturas são perturbadas pelo stress fisiológico crônico, que é medido pela "carga alostática", a 
qual aumenta nas situações de pobreza. Um estudo de Evans e Kim (2012) mostrou que, quanto mais duradoura for a situação de pobreza, menor será a quantidade de informação que os jovens mantêm na memória de trabalho. Este efeito é mediado pelo stress crônico, isto é, a pobreza provoca stress, e o stress afeta a memória de trabalho.

Os estudos são concordantes sobre os efeitos que a pobreza na infância e na adolescência tem na cognição. Najman et al. (2009), por exemplo, mostraram, com mais de 7000 filhos únicos, que a pobreza em qualquer fase da vida até aos 14 anos tem efeitos negativos no desempenho em testes de raciocínio lógico e de leitura de palavras.

O que é que no meio familiar explica a transmissão do Estatuto Social entre as gerações? No domínio da linguagem, até os três anos de idade, os pais mais instruídos falam aos filhos com um vocabulário maior e mais preciso do que o dos menos instruídos, o que se reflete nas crianças, e, quando elas ingressam na escola, o efeito no vocabulário é já muito forte (FARKAS e BERON, 2004). O Estatuto Social, avaliado pela educação da mãe e pelo rendimento familiar, influencia as habilidades de linguagem oral medidas no último ano do pré-escolar, que, por sua vez, influenciam os resultados em leitura e matemática do $2^{\circ}$ ao $4^{\circ}$ anos de escola (DURHAM et al., 2007).

Muito antes de as crianças serem ensinadas a ler, já a sua preparação para a aprendizagem da leitura é influenciada pelo meio sociocultural. A consciência fonológica avaliada na pré-escola está muito mais avançada nas crianças de Estatuto Social alto do que nas de Estatuto baixo e isso se reflete na rapidez da aprendizagem da leitura (DUNCAN e SEYMOUR, 2000). É, portanto, necessário: (1) insistir, na pré-escola, em atividades que estimulem a consciência fonológica de todas as crianças; e (2) conduzir programas de sensibilização e formação junto das famílias de Estatuto Social baixo.

Isto é absolutamente necessário porque as crianças de Estatuto Social baixo correm um risco várias vezes maior de se tornarem más leitoras. Em 20 escolas de Paris foram testadas mais de 1000 crianças: um terço por estatuto (alto, médio e baixo), quase todas do $2^{\circ}$ ano e com pelo menos 18 meses de instrução, pelo que deveriam ser capazes de ler a maior parte das palavras e compreender textos simples (FLUSS et al., 2009). Os alunos que se revelaram maus leitores segundo o critério de pelo menos 12 meses de atraso nos testes de leitura, isto é, que ao fim de 
18 meses não liam sequer como um leitor normal com apenas seis meses de instrução, foram comparados a leitores normais. Revelaram-se inferiores em leitura de palavras $(12 \%$ versus $40 \%)$ e pseudopalavras $(20 \%$ versus $81 \%)$ e em compreensão de texto (11\% versus $53 \%$ ). Apesar de os três níveis de Estatuto Social estarem igualmente representados na amostra inicial, os maus leitores foram $3 \%$ das crianças de meio alto, $11 \%$ das de meio médio, e $24 \%$ das de meio baixo. A criança de Estatuto baixo corre portanto 7 a 8 vezes mais riscos de se tornar má leitora do que a de Estatuto alto.

\subsection{A persistência da plasticidade cerebral, um trunfo para a educação das camadas populares}

Para sabermos até que ponto são irrecuperáveis os efeitos das diferenças de estimulação precoce entre meio rico e meio pobre no desenvolvimento cognitivo ulterior das crianças, até que ponto a escola, em particular através da alfabetização e da literacia, pode compensar esses efeitos, é importante conhecer os limites da plasticidade cerebral. Ora, esses limites não são os mesmos para as diferentes funções cognitivas, até porque o seu desenvolvimento está longe de ser concomitante. As neurociências cognitivas já são altamente informativas a esse respeito e serão ainda mais num futuro muito próximo.

Até há pouco tempo, a opinião dominante era de que os dados estão lançados aos três anos de idade. Hilary Clinton fez eco dessa opinião numa audiência com professores em 2003, dizendo que "quando as crianças iniciam o préescolar já a arquitetura do cérebro foi construída" (HOWARD-JONES et al., 2012). Subjacente estava a ideia de que é preciso privilegiar a educação das crianças que tiveram um bom começo porque os recursos gastos com elas darão os melhores retornos. Essa ideia foi defendida e amplamente divulgada pelo prêmio Nobel de Economia de 2000 James Heckman.

As neurociências estão contribuindo para mudar essa ideia demasiado simples. Um, a aprendizagem tem lugar durante toda a vida. Dois, o cérebro conhece vagas de conectividade neuronal no sentido de uma maior especificidade em vários períodos da vida até a idade adulta. $E$ três, o córtex pré-frontal passa por um longo processo de desenvolvimento até o fim da adolescência, relacionado com 
mudanças importantes em certas funções de controle cognitivo como a atenção seletiva e a memória de trabalho.

Depois da grande infância, o desenvolvimento da flexibilidade cognitiva está associado a uma maior ativação frontal e parietal no hemisfério esquerdo (WENDELKEN et al., 2012). Entre os 8-13 anos e a idade típica do aluno universitário, aumenta a modulação por estruturas frontais e parietais da atividade nas áreas que processam os estímulos, o que indica um melhor controle da atenção em função do objetivo da tarefa (WENDELKEN et al., 2011). Também nessas idades aumentam as interações entre o hipocampo e o córtex pré-frontal, em relação com o desenvolvimento da memória de acontecimentos (GHETTI e BUNGE, 2012).

É possível, portanto, recuperar as crianças socialmente "condenadas" à mediocridade. Nos jovens e adultos, também, continua a ser enorme a proporção dos sub-letrados. Encontrar formas de reintegrar essa população em ciclos educativos apropriados deve ser considerado como um imperativo do ponto de vista humano e social.

\section{QUE É DEMOCRACIA? POR QUE A UNIVERSALIZAÇÃO DA LITERACIA FAZ PARTE DA SUA CONSTRUÇÃO?}

Não existe um conceito natural de democracia. Ele é o que os seres humanos quiserem que seja. Etimologicamente, refere-se ao demo, o povo, e no primeiro meio século de existência dos Estados Unidos da América a democracia foi apresentada como o governo do povo pelo povo e para o povo, mas há uma questão preliminar importante, a de saber o que se entende por povo, como conceito distinto do de população.

Ora, o que é povo varia ao longo da História. Para as sociedades primitivas não se fala de povo, eram demasiado pequenas em número. Nas sociedades da Antiguidade e até nos países desenvolvidos do século XIX, os escravos não faziam parte do povo. E ainda hoje os estrangeiros que residem num país não fazem parte do povo desse país. Além disso, temos a distinção entre o povo e as elites. Se alguém diz "o povo se revolta", podemos ter a certeza de que o povo o faz contra as chamadas elites, elites do dinheiro e do poder. Nesse sentido, nem todos os cidadãos fazem parte do povo. Por conseguinte, seria provavelmente mais justo, 
mais "democrático", considerar que democracia é o governo da população permanente de um país ou de uma reunião de países por ela mesma.

\subsection{Um pouco de História Antiga}

Há mais de dez mil anos, antes da criação e armazenamento de recursos através da pecuária e da agricultura, os caçadores-coletores distribuíam igualitariamente o que caçavam ou colhiam (FISKE, 1992). É possível que essas sociedades, das quais algumas subsistiram e foram estudadas por antropólogos, tivessem praticado uma democracia integral. Com o armazenamento dos recursos, porém, apareceram as desigualdades no acesso aos recursos e portanto também no poder de decisão sobre eles.

A evolução do sistema democrático em Atenas e em algumas outras cidades gregas de menor importância deu-se entre os séculos VIII e V a.C. Pela primeira vez os seres humanos criaram um sistema político que não era justificado pelos deuses mas se baseava em leis decididas de comum acordo ou por maioria e que podiam mudar. A democracia ateniense fundava-se na ideia de que todos os homens livres eram iguais. O reconhecimento da igualdade conduz à imparcialidade. Assim, em Homero, gregos e troianos eram tratados da mesma maneira, tinham o mesmo valor, não havia melhores nem piores; para Heráclito, a razão e o discurso eram universais; e, para os sofistas, todas as ideias e instituições, sem exceção, podiam ser analisadas, criticadas, mudadas. Disse Protágoras que o especialista sabe como realizar uma construção, mas que o povo é que decide se se constrói, quando e para quê. Essas são decisões políticas, a política concerne a todos os cidadãos e concerne-os igualmente.

Antes da reforma de 508 a.C., havia quatro classes censitárias e o sistema favorecia as famílias ricas, excluindo as mais pobres de qualquer direito político. Entre as causas da reforma estava a luta contra as penas pelo não pagamento de dívidas, que podiam ser a prisão e a passagem à situação de escravo. Outra causa era a necessidade de uma larga participação nas decisões sobre as guerras e sobre a participação nelas. A consequência foi o poder político passar para as mãos da maioria, essencialmente as classes médias e populares.

A reforma proclamou a isonomia, igualdade perante a lei, e instaurou uma forma de democracia direta em que todos os cidadãos influenciavam igualmente as 
decisões públicas. A Assembleia do Povo, onde todos podiam usar da palavra e votar, era convocada por um Conselho. Reunia em média cinco mil pessoas, sendo seis mil requeridas para as decisões importantes. Todas as decisões obedeciam à regra da maioria. Uma compensação financeira permitia aos pobres participar no Conselho, na Assembleia e nos tribunais.

A designação para o Conselho, para o governo de Atenas e para os tribunais populares não se fazia por eleição, considerada então princípio aristocrático e hoje uma característica definidora da democracia representativa, mas por sorteio entre os cidadãos. O presidente da Assembleia também era sorteado no seu seio, para que não pudesse controlá-la. Só os estrategos, que dirigiam as forças militares, eram eleitos. Um dos instrumentos da democracia ateniense era o controle dos mandatos de gestor dos fundos públicos. Enfim, a rotatividade dos cargos (os membros do Conselho eram designados por um ano) contribuía para impedir a formação de uma elite política permanente.

$\mathrm{Na}$ Grécia antiga, o demos era portanto a totalidade dos homens livres e iguais em direitos. Acontecia, porém, que entre os 400 mil habitantes de Atenas no século V, só 40 mil eram homens livres. Tinham de ter pelo menos 20 anos, ser filhos de atenienses e ter o serviço militar cumprido para poderem participar na Assembleia. Não tinham direitos políticos, para além das crianças (cerca de $80 \mathrm{mil}$ ), as mulheres, os estrangeiros (60 mil) e os escravos (180 mil). Eram as duas últimas categorias que, submetidas à minoria de homens livres, mais contribuíam para a prosperidade da cidade. Atenas era uma democracia inserida num sistema machista e escravagista.

Este sistema de governo não era do agrado de todos, mas de diferentes maneiras. Na polis ideal de Aristóteles, os cidadãos capazes de governar e de serem governados eram os que dispunham de sabedoria prática e cultivavam a virtude cívica subordinada ao exercício da razão abstrata, e por isso Aristóteles excluía os indivíduos que contribuíam para a desintegração da vida comunitária assim como os trabalhadores manuais, os agricultores e os marinheiros. Em contrapartida, os estoicos achavam que todo o ser humano é dotado de uma dignidade merecedora de igual respeito e que tanto os escravos como os indivíduos livres, as mulheres como os homens, os pobres como os ricos, têm a capacidade de fazer juízos morais. 


\subsection{Um pouco de História Moderna}

Considera-se hoje que a democracia só renasceu com o movimento de independência norte-americana e com a Revolução Francesa. Esta é uma visão simultaneamente ocidental e liberal, mas é falsa. Amartya Sen (2011), prêmio Nobel de economia em 1998, lembra as experiências de democracia que houve na Ásia antiga, em particular na Índia e no Irã, e que mostram que a democracia não é um puro produto ocidental. O que para ele é mais característico da democracia ateniense não são os processos de decisão, mas a existência de um debate público aberto. Sob a influência provável de Atenas, muitos governos municipais em cidades da Ásia integraram elementos de democracia como a existência de uma assembleia popular e a eleição por ele de um conselho e de magistrados.

A visão liberal da história da democracia é desmontada num livro de Francis Dupuis-Déri (2013), intitulado Democracia: história política de uma palavra. Ele lembra que, durante a Idade Média e o Renascimento, milhares de aldeias dispunham de uma assembleia de habitantes que tomavam em comum as decisões relativas à coletividade (ceifas, partilha da colheita comum, corte de madeira nas terras comunais, restauro das pontes, poços e moinhos, contratação do professor primário, dos pastores, dos guardas florestais, designação dos que serviriam na milícia e do representante junto da corte, alojamento das tropas reais, etc.). As "comunidades de habitantes" dispunham de estatuto jurídico e funcionaram durante séculos segundo o modo da autogestão. Os reis e os nobres contentavam-se em gerir as questões relacionadas com a guerra e os seus domínios privados, administrar a justiça, impor taxas e corveias, e não ingeriam nas questões da comunidade.

Havia entre 10 e 15 assembleias por ano, necessariamente num lugar público, em que as mulheres também participavam. A regra era que 10 pessoas chegavam para formar um "povo" e reunir a assembleia, mas esta podia reunir centenas de pessoas. A participação era obrigatória e os ausentes eram multados quando a questão era importante (por exemplo, alienar uma parte dos bens comuns, decisão que requeria um quórum de 2/3). O voto fazia-se levantando a mão, ou por aclamação, ou ainda distinguindo os "por" e os "contra" por meio de bolas brancas e pretas. 
Para além das assembleias de comunidade havia as federais, que reuniam várias comunidades, e nas cidades de alguns milhares de habitantes havia assembleias que podiam reunir 800 habitantes ou mais. Havia também assembleias de guildas de comerciantes e artesãos (os mestres e os aprendizes reuniam-se por vezes juntos e por vezes separados). Assim, na Europa medieval, população e território estavam submetidos a vários tipos de regime político: autoritário (monarquia para o reino, aristocracia para a região) e igualitário (democracia local e profissional). Mas a autonomia das comunidades e das associações profissionais foi decrescendo à medida que o Estado-nação foi ganhando poder. Os conflitos aumentaram, as assembleias foram proibidas, e o rei passou a nomear prefeitos para dirigir as comunidades.

O que ficou registrado na História não reflete provavelmente a quantidade de ocorrências no tempo e no espaço das experiências de democracia autenticamente popular. Tanto Sen como Dupuis-Déry, nos dois livros que mencionei, citam uma passagem de Mandela no seu livro Um longo caminho para a liberdade a propósito das reuniões locais da sua juventude: "Quem quisesse falar podia fazê-lo e era ouvido, era a democracia na sua forma mais pura."

Muitas comunidades devem ter conhecido um regime de verdadeira democracia, mas até recentemente a palavra "democracia" nunca fora utilizada para designar o seu funcionamento político. No banco de dados informáticos do Instituto Nacional da Língua Francesa, só há duas ocorrências da palavra democracia do século XVI até perto de metade do século XVIII. A palavra democracia passou a ser mais utilizada no período da independência norte-americana e da Revolução Francesa, mas quase sempre com um sentido pejorativo: o governo popular era considerado uma fonte de desordem. Na realidade, os teóricos e os militantes desses movimentos não pretendiam fundar uma democracia, e teriam ficado muito surpresos se soubessem que hoje são considerados como democratas.

O regime eleitoral liberal, considerado hoje modelo de democracia, foi fundado por antidemocratas declarados. John Adams, primeiro vice-presidente dos Estados Unidos e presidente depois de George Washington, disse que a democracia "é um governo arbitrário, tirânico, sangrento, cruel e intolerável" e que "a simples democracia nunca teve defensores entre os homens de letras". Ele e os outros independentistas identificavam-se à república, um regime fundado em eleições (na época, censitárias e reservadas aos homens), expressão da virtude e da 
legitimidade e que seduziu uma parte importante da nobreza. Democracia ainda era então o que sempre fora, isto é, democracia direta, apresentada como um regime em que os pobres oprimem e massacram os ricos e acaba por ser prejudicial ao próprio povo.

A soberania do povo era aceita em teoria, desde que o seu exercício coubesse à elite. Em 1776, John Adams declarou que o povo é o pior guardião da sua própria liberdade, porque não pode "nem agir, nem julgar, nem pensar, nem querer", e porque os representantes eleitos, como ele, são mais inteligentes do que o povo que representam. Na correspondência entre Adams e Thomas Jefferson, principal redator da Declaração de Independência e terceiro presidente dos Estados Unidos, foi explicitamente dito que há uma aristocracia natural, fundada no talento e na virtude, destinada ao governo das sociedades, e que a melhor forma política é a que permite identificar esses aristocratas naturais. Etimologicamente, aristocracia é o poder dos melhores.

A aristocracia estava também associada à propriedade. Para Adams, os que não dispõem da propriedade também não dispõem da virtude, um termo que na época designava a competência política. Na Convenção de Filadélfia, de 1787, Alexandre Hamilton explicou que a democracia é um ataque à propriedade privada. Os ricos e os bem-nascidos controlam a massa instável do povo, e como não esperam nenhuma vantagem de uma mudança vão fazer um bom governo. Para Adams, os pobres são destinados ao labor e os ricos qualificados para as funções superiores em razão da sua educação e independência.

$\mathrm{Na}$ França, Emmanuel Sieyès, deputado da Assembleia Nacional, afirmou que o povo é incapaz de se governar e "não pode falar, não pode agir senão através dos seus representantes". Também Robespierre e Constant, embora tivessem posições políticas muito diferentes, rejeitaram o governo pelo povo sem no entanto pretenderem que o povo se pudesse fazer representar: Robespierre disse que só por ficção a lei é a expressão da vontade geral, e Constant que exercer a soberania por representação é exercê-la de maneira fictícia. Rousseau disse o mesmo, mas com a intenção oposta: "Os deputados do povo não são nem podem ser os seus representantes. (...) O povo inglês pensa ser livre; ele se engana, só o é durante a eleição dos membros do Parlamento; logo que estes são eleitos, é escravo, não é nada". 
De fato, a eleição é um reconhecimento de elitismo. Quando a designação se faz por eleição, dizia Aristóteles, a situação é aristocrática. Spinoza também se pronunciou no mesmo sentido: "A aristocracia distingue-se da democracia, principalmente pelo fato de que na primeira a qualificação para o poder político depende de uma escolha". A mesma ideia foi expressa por Rousseau e por Montesquieu. Até há pouco menos de 200 anos, só raros autores associaram democracia e eleição.

A mudança de sentido da palavra democracia e a sua associação à eleição de representantes deu-se, nos Estados Unidos por volta de 1830, nomeadamente com o presidente Andrew Jackson, e na França pouco depois. As elites políticas passaram a apresentar-se como democratas a fim de consolidarem a sua legitimidade junto do povo. A referência à democracia passou a ser um trunfo eleitoral. Assim, a palavra democracia entrou no jogo do marketing político e nunca mais de lá saiu.

Dupuis-Déri chama agorafobia política ao medo da democracia direta. Ágora era a praça pública em que os cidadãos gregos se reuniam para deliberar. Hoje, um cidadão que não foi eleito não pode participar nas deliberações. As portas da ágora abrem-se na democracia direta para deixar entrar e falar todos os cidadãos, enquanto na democracia representativa as do parlamento se fecham para o discurso popular, só deixando falar os cidadãos eleitos. Para a agorafobia política, o povo é irracional, não controla as suas paixões e não pode governar para o bem comum. Para a agorafilia política, é a elite governante que é irracional, dominada pela sua paixão pelo poder e pela glória.

Num livro publicado em França em 1837, a velha democracia, a da Grécia antiga, era caracterizada assim: "haverá domínio mais cego e mais tirânico que o das massas que não têm nada, não sabem nada, invejam tudo e proscrevem o mérito e a fortuna que lhes fazem sombra?" Por volta de 1860, a nova democracia é apresentada como razoável, pacífica, observadora da lei. Como escreve Dupuis-Déri, no espaço de duas ou três gerações, a palavra democracia, que durante mais de dois mil anos significou o governo do povo pelo povo, passou a designar um regime em que um punhado de políticos eleitos tomam as decisões em nome do povo. Até Hitler, na segunda metade dos anos XX, quis aproveitar a aura da palavra democracia e prometeu à Alemanha a futura "democracia germânica". 
A manipulação do sentido da palavra "democracia" tivera como precursora uma outra, a das palavras liberal e liberalismo, apoiada no conceito de liberdade. Esse processo começou com Locke, o pai do liberalismo, que não preconizou a liberdade de todos os seres humanos, mas a de se apoderar da vida e do trabalho dos escravos negros, assim como das terras habitadas pelos índios desde há muitas gerações. Esse filósofo inglês foi um dos acionistas da Royal African Company, que investiu no tráfico dos escravos. Enquanto secretário do Conselho do Comércio e Plantações, ele tinha interesse pessoal no avanço expansionista das colônias brancas na América do Norte. Note-se que 10 dos 14 primeiros presidentes dos Estados Unidos foram grandes proprietários de escravos.

Ao longo dos dois séculos que se seguiram, tornou-se cada vez mais patente um paradoxo que, na realidade, tem uma explicação muito simples. Como diz Domenico Losurdo, no seu livro Contra-história do liberalismo, não é correto dizer que a escravatura persistiu mau grado o sucesso das três revoluções liberais, a holandesa, a inglesa e a norte-americana. Foi exatamente o contrário que se passou: a escravatura foi alimentada por essas revoluções. Na América do Norte, a população escrava, que tinha sido de 330 mil no início do século XVIII passou para 3 milhões no fim desse século e atingiu mais de 6 milhões no meio do século XIX. Essa mão de obra foi crucial para estabelecer e consolidar o capitalismo.

Entretanto, a dinâmica capitalista conduziu ao desenvolvimento das forças produtivas e à necessidade de estender a alfabetização e a instrução a uma parte cada vez maior da população. A expansão da instrução, por sua vez, pôs em cheque a crença de que o povo, sendo irracional e ignorante, não se pode governar a si mesmo, e contribuiu para o fortalecimento e a vitória dos movimentos abolicionistas.

Atualmente, o trabalho industrial deixou de ser prevalente, ultrapassado pelo trabalho nos serviços e pelo trabalho intelectual que em parte se sobrepõem. Entre os trabalhadores intelectuais, um setor numericamente importante é o dos professores de todos os níveis de ensino, que na sua maioria tendem cada vez mais a tornar-se intelectuais proletarizados. O desenvolvimento do capitalismo da automação e da robótica está criando uma enorme massa popular constituída por todos esses tipos de trabalhadores e pelos sem-trabalho. Eles não são mais irracionais e ignorantes, ao contrário do que se pretendia que o povo era na época do liberalismo clássico, e eles vão cada vez mais exigir a velha democracia, a democracia direta. 
Nesse sentido, criar leitores faz parte de uma dinâmica democrática e anticapitalista. Democracia é debate e decisão: debate aberto a todos e decisão tomada coletivamente pela maioria. A literacia não é uma condição necessária à democracia, mas a sua generalização põe cada um em condições de debater e de contribuir de maneira informada para a decisão de todos.

\subsection{Os modelos ideológicos da literacia e da educação}

A literacia e a educação são vistas de modo totalmente diferente por dois modelos ideológicos, o do "capital humano" e o das "capacitações".

O conceito de "capital humano" refere-se ao conjunto de habilidades e qualificações que influenciam a produtividade e o rendimento do indivíduo na economia. Walsh (1935) formulou-o como "o investimento realizado nas capacidades profissionais" e comparou-o ao investimento no "capital material". Gary Becker, prêmio Nobel de economia em 1992, elaborou o conceito e contribuiu muito para o seu prestígio. A ideia de que "a teoria do capital se aplica ao homem" tem implicações para a literacia e a educação em geral.

A imagem que este modelo dá dos seres humanos é a de produtores econômicos e de cidadãos consumidores, movidos pelo seu autointeresse, racionais, calculadores do melhor ratio benefício/custo (WALKER, 2012). O indivíduo assumese como um valor econômico e procura otimizá-lo. Julga-se ator num mercado (o de trabalho), investidor dele mesmo, possuidor de valor e de meios para se afirmar.

A educação deixa de ser orientada para a formação de indivíduos livres, sujeitos e criadores de conhecimento, portadores de valores éticos e de capacidade crítica, para se tornar "investimento na formação de capital humano". Neste contexto, um estudo realizado no Brasil (FLORES-MENDOZA et al., 2012), depois de confirmar o fato de o QI médio do país ser muito fraco (89), mostrou que o QI da população dos estudantes do ensino superior que frequenta as universidades públicas é muito superior ao dos que frequentam universidades privadas e comparável ao dos estudantes dos países desenvolvidos. Ora, as universidades públicas, que são as melhores, são frequentadas por apensa $10 \%$ dos estudantes. Por conseguinte, para os autores, o "capital humano" de alto nível do Brasil corresponderia aproximativamente a $10 \%$ da população, isto é, 20 milhões de indivíduos, e 20 milhões seriam suficientes para garantir a liderança que o Brasil 
exerce atualmente na América Latina, o que tornaria inútil a criação de outras universidades públicas. Não dizem nem uma palavra a respeito da educação dos restantes 180 milhões. A mensagem implícita é que não se deve criar boas universidades para mau capital humano.

Na perspectiva do capital humano, os objetivos da educação das crianças e dos adolescentes são o crescimento econômico, a competitividade, o rendimento e a empregabilidade, isto é, os valores instrumentais do mercado. Os jovens das classes baixas são educados para a aceitação das normas sociais e a adaptação ao mercado, e os das elites para serem "indomáveis lobos solitários sem necessidade de mais ninguém do que deles mesmos" (BAPTISTE, 2001), ativos, empreendedores e flexíveis. Esses podem escolher os melhores empregos na sociedade internacional global, orgulhosos de serem presas na caça realizada pela nova meritocracia aos cérebros e aos talentos (BROWN e TANNOCK, 2009).

Vejamos agora o modelo adversário, o das capacitações, proposto por Amartya Sen em Desenvolvimento como liberdade (2010) e A ideia de justiça (2011). Baseia-se no princípio de que o que determina o desenvolvimento e a qualidade de vida de um país não é o crescimento econômico, mas o que as pessoas são capazes de fazer e de ser a partir das suas capacitações e do contexto econômico, social e político em que vivem. A sociedade deveria promover um conjunto de liberdades substanciais que os indivíduos poderão decidir se exercem ou não. Uma sociedade que não fornece educação nem estimula o desenvolvimento das capacidades mentais de uma parte da população não the oferece uma liberdade substancial.

Na mesma linha, Martha Nussbaum (2011) defendeu que a educação é essencial para o desenvolvimento e o exercício de numerosas capacitações, é um "funcionamento fértil" da maior importância para afrontar as desigualdades crescentes. A alfabetização e a literacia fazem parte das condições mínimas universais sem as quais não se pode alcançar o bem-estar. Ajudam a reduzir o desemprego, a insegurança e o sentimento de privação, e a aumentar o nível de saúde e de participação nas atividades políticas.

Nussbaum começa o seu livro Not for profit: why democracy needs the humanities, de 2010, dizendo que estamos mergulhados numa crise tremenda, prenhe de graves consequências mundiais. Logo depois, esclarece que não se trata da atual crise econômica, mas de uma crise que no seu início passa despercebida 
como um cancro e que pode ser bem mais devastadora para a democracia: a crise mundial da educação. Os Estados enveredaram por sistemas educativos que desprezam os instrumentos indispensáveis à sobrevivência da democracia e que produzirão máquinas eficazes, mas não cidadãos capazes de pensar por si mesmos e de compreender o que significam os sofrimentos e os sucessos dos outros. As artes e as humanidades foram amputadas em todos os ciclos de ensino. Preferindo cultivar as qualificações técnicas altamente especializadas para se manterem competitivos no mercado mundial, os detentores do poder político desembaraçaramse de todos os elementos que consideravam inúteis. Ora, o pensamento crítico, a capacidade de ultrapassar os interesses locais para enfrentar os mundiais, e a capacidade de reagir com empatia às dificuldades dos outros dependem do estudo das humanidades e das artes.

Uma palavra sobre os mais altos níveis de formação. A integração do ensino e da ciência na economia de mercado conduz a uma privatização progressiva da despesa educativa. A parte dos fundos privados ainda é inferior a 5\% na Dinamarca, na Noruega e na Finlândia, mas já ultrapassa $40 \%$ na Austrália, no Canadá, nos Estados Unidos e no Japão (dados da OCDE de 2009). A hiperseleção à entrada conduz ao desenvolvimento de uma "escola da sombra": o setor mercantil recruta os melhores professores e oferece aos alunos estágios intensivos, sessões de coaching particular, aulas de preparação, tudo a altos preços. Essas empresas beneficiam-se com as fraquezas do ensino público. O prestador de serviço oferece algo de individualizado que o ensino público de massa não pode dar, e são sobretudo os bons alunos, de classe média ou rica, que podem recorrer a ele. $\mathrm{Na}$ perspectiva do capital humano, a educação enriquece (uma minoria).

Gaston Bachelard (1996) sonhava com uma sociedade feita para a escola, não com uma escola feita para a sociedade. Os fins da escola não podem subordinar-se aos da sociedade atual porque a escola deve formar os homens e cidadãos do futuro. Importa portanto que os governos, os poderes econômicos e as instituições ideológicas (igrejas, partidos) respeitem a sua autonomia e dois princípios básicos: que nem a humanidade do homem se reduz ao produtorconsumidor, nem a cultura se reduz a um corpus de saberes operacionais e rentáveis.

Como escreveu Pena-Ruiz (2005), a mutação incessante dos saberes torna vãs as formações qualificantes a curto prazo que fecham o futuro trabalhador na 
unidimensionalidade de um ofício. A relegação da cultura geral é obscurantismo e inconsciência. Só uma cultura geral sólida, feita de saberes fundamentais, permite uma capacidade de adaptação a novos problemas e técnicas.

Volto ao livro de Nussbaum (2010) para concluir com as mesmas palavras com que ela o concluiu: se não insistimos na importância crucial das humanidades e das artes, elas desaparecerão porque não produzem dinheiro. Mas elas oferecem um mundo em que vale a pena viver.

\title{
NOTAS
}

1 Parte da informação contida neste artigo foi extraída de dois livros do autor: Criar Leitores, publicado pela Editora Manole, de São Paulo, em 2013, e, sobretudo, "Alfabetizar em Democracia", publicado em Lisboa pela Fundação Francisco Manuel dos Santos, em 2013. O último livro será publicado em 2014 em versão brasileira, adaptada à realidade do Brasil, pela Editora Penso, de Porto Alegre.

2 Professor da Université Libre de Bruxelles, Bélgica (ULB Institute of Neuroscience). E-mail: jmorais@ulb.ac.be.

\section{LITERACY FOR DEMOCRACY}

\begin{abstract}
After a brief description of the three conditions or phases of alphabetic reading and spelling learning, I examine the consequences of socioeconomic and sociocultural inequalities both on the beginning and the development of literacy and, more generally, on cognitive development. Given that the access to literacy for all or, on the contrary, only for an elite has also consequences for the society governance, in the third and final part of this paper I discuss what, through many centuries, had been democracy and what it should be, as well as the contribution that the universalization of literacy and of a culture based on free thinking may have for constructing an authentic democracy.
\end{abstract}

Keywords: Literacy. Learning an alphabet. Brain plasticity. Socioeconomic inequalities. Democracy. Education. 


\section{ALPHABETISER POUR LA DEMOCRATIE}

\section{RESUME}

Après une brève description des trois conditions ou phases de l'apprentissage de la lecture et de l'écriture dans un système alphabétique, j'examine les conséquences des inégalités socioéconomiques et socioculturelles aussi bien sur l'entrée dans de processus d'alphabétisation et son décours que sur le développement cognitif en général. Puisque l'accès à la litératie pour tous ou, au contraire, juste pour une élite a aussi des conséquences sur le mode de gouvernement de la société, dans la troisième et dernière partie de cet article je discute ce que la démocratie a été à travers les siècles et ce qu'elle devrait être, ainsi que la contribution que l'universalisation de la litératie et d'une culture fondée sur la pensée libre et critique peut avoir sur la construction d'une vraie démocratie.

Mots-clés : Litératie. Alphabétisation. Plasticité cérébrale. Inégalités socioéconomiques. Démocratie. Éducation.

\section{REFERÊNCIAS}

BACKERMANS-KRANENBURG, M. J. et al. Experimental evidence for differential susceptibility: Dopamine D4 receptor polymorphism (DRD4 VNTR) moderates intervention effects on toddlers' externalizing behavior in a randomized controlled trial. Developmental Psychology, 44, p. 293-300, 2008.

BACHELARD, Gaston. A formação do espírito científico: contribuição para uma psicanálise do conhecimento. Rio de Janeiro: Contraponto, 1996.

BAPTISTE, lan. Educating lone wolves: pedagogical implications of human capital theory. Adult Education Quarterly, 51, p. 184-201, 2001.

BRINCH, C. N.; GALLOWAY, T. A. Schooling in adolescence raises IQ scores. Proceedings of the National Academy of Sciences of the United States, 109, p. 425430, 2012.

BROWN, P.; TANNOCK, S. Education, meritocracy, and the global war for talent. Journal of Education Policy, 29, p. 377-392, 2009. 
BUCHWEITZ, A. et al. Brain activation for reading and listening comprehension: An fMRI study of modality effects and individual differences in language comprehension. Psychology \& Neuroscience, 2, p. 111 - 123, 2009.

COHEN, L. et al. The visual word form area : Spatial and temporal characteristics of an initial stage of reading in normal subjects and posterior splitbrain patients. Brain, 123, p. 291-307, 2000.

DEHAENE, S. et al. How learning to read changes the cortical networks for vision and language. Science, 330, p. 1359-1364, 2010.

DUNCAN, L. G.; SEYMOUR, P. H. Socio-economic differences in foundation-level literacy. British Journal of Psychology, 91, p. 145-166, 2000.

DUPUIS-DERI, Francis. Démocratie: histoire politique d'un mot. Montreal: Lux, 2013.

DURHAM, R. E. et al. Kindergarten oral language skill : a key variable in the intergenerational transmission of socioeconomic status. Research in Social Stratification and Mobility, 25, p. 294-305, 2007.

EVANS, G. W.; KIM, P. Childhood poverty and young adult allostatic load: the mediating role of childhood cumulative risk exposure. Psychological Science, 23, p. 979-983, 2012.

FARKAS, G.; BERON, K. The detailed age trajectory of oral vocabulary knowledge: differences by class and race. Social Science Research, 33, p. 464-497, 2004.

FISKE, A. P. The four elementary form of sociality: framework for a unified theory of social relations. Psychological Review, 99, p. 689-723, 1992.

FLORES-MENDOZA, C. et al. Considerations about IQ and human capital in Brazil. Temas em Psicologia, 20, p. 133-154, 2012.

FLUSS, J. et al. Poor reading in French elementary school: the interplay of cognitive, behavioral, and socioeconomic factor. Journal of Developmental and Behavioral Pediatrics, 30, p. 206-216, 2009.

GHETTI, S.; BUNGE, S. A. Neural changes underlying the development of episodic memory during middle childhood. Developmental Cognitive Neuroscience, 2, p. 381395, 2012.

HOWARD-JONES, P. A.; WASHBROOK, E. V.; MEADOWS, S. The timing of educational investment: a neuroscientific perspective. Developmental Cognitive Neuroscience, 2, S18-S29, 2012.

LAGER, A. C.; TORSSANDER, J. Causal effect of education on mortality in a quasiexperiment on 1.2 million Swedes. Proceedings of the National Academy of Sciences of the United Sates, 109, p. 8461-8466, 2012. 
LIBERMAN, A. M. The relation of speech to reading and writing. In: DE GELDER, B.; MORAIS, J. (Eds.). Speech and reading: a comparative approach. Hove, UK: Erlbaum Taylor \& Francis, 1995. p. 17-31.

LOSURDO, Domenico. Contra-história do liberalismo. Trad. Giovanni Semerano. Aparecida, SP: Idéias \& Letras, 2006.

LUBY, J. L. et al. Maternal support in early childhood predicts larger hippocampal volumes at school age. Proceedings of the National Academy of Sciences of the United States, 109, p. 2854-2859, 2012.

MALONEY, E. ; RISKO, E. F. ; O'MALLEY, S. Tracking the transition from sublexical to lexical processing : on the creation of orthographic and phonological lexical representations. Quarterly Journal of Experimental Psychology, v. 62, p. 858-867, 2009.

MORAIS, J. et al. Does awareness of speech as a sequence of phonemes arise spontaneously? Cognition, 7, p. 323-331, 1979.

MORAIS, J. A arte de ler. São Paulo: UNESP, 1996.

NAJMAN, J. M. The impact of episodic and chronic poverty on child cognitive development. Journal of Pediatrics, 154, p. 284-289, 2009.

NEEDHAM, B. L. et al. Socioeconomic status and cell aging in children. Social Science \& Medicine, 74, p. 1948-1951, 2012.

NUSSBAUM, M. C. Creating capabilities: the human development approach. Cambridge, MA: Harvard University Press, 2011.

NUSSBAUM, M. C. Not for profit: why democracy needs the humanities. Princeton, NJ: Princeton University Press, 2010.

PENA-RUIZ, H. Qu'est-ce que l'école? Paris: Gallimard, 2005.

SEN, A. Desenvolvimento como liberdade. Trad. Laura Teixeira Motta. São Paulo: Companhia das Letras, 2010.

A ideia de justiça. Trad. Denise Bottmann e Ricardo Donnelli Mendes. São Paulo : Companhia das Letras, 2011.

TEMPLE, E. et al. Disrupted neural responses to phonological and orthographic processing in dyslexic children : an fMRI study. NeuroReport, v. 12, p. 299-307, 2004.

TUCKER-DROB, E. M. Preschools reduce early academic-achievement gaps: a longitudinal twin approach. Psychological Science, 23, p. 310-319, 2012.

TURKHEIMER, E. et al. Socioeconomic status modifies heritability of IQ in young children. Psychological Science, 14, p. 623-628, 2003. 
WALKER, M. A capital or capabilities education narrative in a world of staggering inequalities? International Journal of Educational Development, 32, p. 384-393, 2012.

WALSH, J. R. Capital concept applied to man. Quarterly Journal of Economics, 2, p. 255-285, 1935.

WENDELKEN, C. et al. Neural indices of improved attentional modulation over middle childhood. Developmental Cognitive Neuroscience, 1, p. 175-186, 2011.

WENDELKEN, C. et al. Flexible rule use: common neural substrates in children and adults. Developmental Cognitive Neuroscience, 2, p. 329-339, 2012. 